\title{
Influence of Isolated PGPR Rhizobacteria in Central and Northern Benin on Maize Germination and Greenhouse Growth
}

\author{
Olaréwadjou Amogou1, Gustave Dagbénonbakin², Nadège Adoukè Agbodjato1, \\ Pacôme Agossou Noumavo ${ }^{1,3}$, Hafiz Adio Salami' ${ }^{1}$, Salako Valère ${ }^{4}$, \\ Aguegue Mèvognon Ricardos' ${ }^{1}$, Assogba Abado Sylvestre ${ }^{1}$, Koda Fousseni Abdel Djihal', \\ Adolphe Adjanohoun ${ }^{5}$, Lamine Baba-Moussa ${ }^{*}$
}

\footnotetext{
${ }^{1}$ Département de Biochimie et de Bio-logie Cellulaire, Faculté des Sciences et Techniques (FAST), Laboratoire de Biologie et de Typage Moléculaire en Microbiologie, Université d’Abomey-Calavi (UAC), Cotonou, Bénin

${ }^{2}$ Centre de Recherches Agricoles d’Agonkanmey, Institut National des Recherches Agricoles du Bénin, Cotonou, Bénin

${ }^{3}$ Département de Biologie Végétale, Laboratoire de Microbiologie et des Technologies Alimentaires, Cotonou, Bénin

${ }^{4}$ Faculté des Science Agronomique (FSA), Laboratoire de Biomathématique et d'Estimation Forestière,

Université d'Abomey-Calavi (UAC), Cotonou, Bénin

${ }^{5}$ Centre de Recherches Agricoles Sud, Institut National des Recherches Agricoles du Bénin, Attogon, Bénin

Email: *lamin esaid@yahoo.fr
}

How to cite this paper: Amogou, O., Dagbénonbakin, G., Agbodjato, N.A., Noumavo, P.A., Salami, H.A., Valère, S., Ricardos, A.M., Sylvestre, A.A., Djihal, K.F.A., Adjanohoun, A. and Baba-Moussa, L. (2018) Influence of Isolated PGPR Rhizobacteria in Central and Northern Benin on Maize Germination and Greenhouse Growth. American Journal of Plant Sciences, 9, 2775-2793.

https://doi.org/10.4236/ajps.2018.913201

Received: December 3, 2018

Accepted: December 26, 2018

Published: December 29, 2018

Copyright $\odot 2018$ by author(s) and Scientific Research Publishing Inc. This work is licensed under the Creative Commons Attribution International License (CC BY 4.0).

http://creativecommons.org/licenses/by/4.0/

c) (i) Open Access

\begin{abstract}
The objective of the study was to evaluate the effects of nine plant growth-promoting rhizobacteria (PGPR) alone or in combination on maize seed germination and seedling growth under laboratory and greenhouse conditions. The germination and growth tests were carried out in square petri dishes and pots. Maize seeds were inoculated with suspension of $10^{8} \mathrm{CFU} / \mathrm{ml}$ of rhizobacteria. The experimental device was a random block of 16 treatments with four repetitions. Germination test results showed that seeds inoculated with PGPR including the control induced good germination in the range of $93.75 \%$ to $100 \%$. The vigor index and root length of the seeds treated with Bacillus panthothenicus were significantly improved by $76.64 \%$ and $58.86 \%$, respectively, while the maximal lengths of the seedlings were obtained with Pseudomonas cichorii with an increase of $118.95 \%$. In greenhouse experience, data demonstrated that Serratia marcescens better improved the leaf area, height and underground biomass, respectively by $58.83 \%, 108.43 \%$, and $59.16 \%$ as compared to the control. The highest fresh aerial biomass and air dry matter was obtained with plants treated only with Pseudomonas puti$d a$. These results show the potential to use such rhizobacteria as biofertilizers to improve maize productivity in Benin.
\end{abstract}




\section{Keywords}

PGPR, Biofertilization, Germination, Growth, Soil Ferruginous

\section{Introduction}

Maize (Zea mays L.) is one of the most important cereal crops in the world [1] [2]. In Benin, maize production plays a strategic role in the food security of rural and urban populations and also provides income for farmers [3]. Indeed, the practice of maize cultivation represents a source of permanent and part-time jobs for more than one million Beninese [4]. Currently, it is the most consumed cereal by the population and nearly a $1 / 3$ of agricultural areas sown are devoted for its production [5] [6]. Maize enjoys a prestigious image and its demand grows steadily. Its annual consumption is estimated to be $5 \%$ between the period 1996 and 2016 [7]. Despite its importance, the national grain yields of maize are still low compared to the estimated plant potential of 3 to $5 \mathrm{t} / \mathrm{ha}^{-1}$ [8]. In 2015, the national maize production deficit was $613,940 \mathrm{t}$ [9]. One of the reasons for this situation is the continued decline in fertility of cultivated soils. Thus, the fertility of the land is the limiting factor of the increase in yields. The production of maize in order to ensure food safety and substantial income to producers is still dependent on the intensive use of mineral fertilizers. This approach can lead not only to a significant reduction in food production but also to declining soil fertility and biological elements [10]. It should also be added that the misuse of these mineral fertilizers also has adverse effects on human health and the environment [11]. In the face of this problem, improving soil fertility is one of the common strategies for increasing agricultural production. Thus, any realistic approach to reducing the contribution of pesticides and chemical fertilizers on the one hand and improving crop yield and soil quality deserves to be exploited. To do this, the method of inoculation of cultures by microorganisms such as PGPR "Plant Growth promoting Rhizobacteria" is considered a promising strategy to ensure the maintenance and regularity of production without health risk and with less dependence on chemical fertilizers. Indeed, PGPR is soil bacteria that aggressively colonizes plant roots in general at the rhizosphere level and in particular the roots of wheat, maize, etc. [12] [13] when applied to seed [14]. Their interactions with plants are known to increase the growth and health of the plant host [15]. Several researchers [16] [17] [18] confirmed positive results on rice, wheat and cucumber crops inoculated by PGPR Rhizobacteria. In addition, the work of [19] showed that the application of PGPR on barley seedlings improved the nitrogen and phosphorus content. In southern Benin, [20] reported that inoculation of maize grains by PGPR Rhizobacteria improved seed germination and controlled growth of maize plants. The objective of this study is to evaluate the effects of nine (09) rhizobacteria (PGPR) isolated and identified 
in central and northern Benin on in vitro germination and growth of maize under greenhouse.

\section{Material and Methods}

\subsection{Material}

Corn Seeds: The maize seeds used are those of the variety EVDT 97 STR C1 from the South Agricultural Research Centre (CRA-Sud) of the National Agricultural Research Institute of Benin (INRAB). This variety has good resistance to american rust, streak, blight, curvulariose, and drought [21].

Strains of PGPR: Nine (9) strains of PGPR namely Bacillus polymyxa, Bacillus anthracis, Bacillus thuringiensis, Bacillus circulans, Bacillus panthothenicus, Pseudomonas cichorii, Pseudomonas putida, Pseudomonas syringae and Serratia marcescens were used. These strains were isolated and characterized from the rhizosphere of maize from the different agroecological zones of central and northern Benin by [22] and stored at $-20.3^{\circ} \mathrm{C}$ in Muller Hinton broth with glycerol $(10 \%)$ in the laboratory of Biology and molecular typing in microbiology from the University of Abomey-Calavi.

\subsection{Methods}

\subsubsection{Preparation of PGPR Inoculum}

The method described by [23] was used to rejuvenate the three (3) Pseudomonas strains on King B medium. Strains of Bacillus and Serratia were revived on nutrient agar [24] [25]. The inoculum of each PGPR was obtained by culture in a nutrient medium ( $\mathrm{MH}$ liquid) for $24 \mathrm{~h}$ at $30^{\circ} \mathrm{C}$. The method described by [26] allowed us to adjust bacterial cultures to a concentration of about $1 \times 10^{8} \mathrm{CFU} / \mathrm{ml}$ (0D 0.45 to $610 \mathrm{~nm}$ ) with a spectrophotometer 24 hours after incubation.

\subsubsection{Experimental Device}

The device adopted was a complete random block with sixteen (16) treatments with four (04) repetitions. The treatments were defined as: CTL: Control without bacteria, B1: Bacillus polymysa, B2: Bacillus anthracis, B3: Bacillus circulans, B4: Bacillus thuringiensis, B5: Bacillus panthothenicus, P1: Pseudomonas cichorii, P2: Pseudomonas putida, P3: Pseudomonas syringae, S. m: Serratia marcescens, B1B2B3B4B5: Bacillus polymysa-Bacillus anthracis-Bacillus circulans-Bacillus thuringiensis-Bacillus panthothenicus, B4B5S.m: Bacillus thuringiensis-Bacillus panthothenicus-Serratia marcescens, P1P2P3: Pseudomonas cichorii-Pseudomonas putid-pseudomonas syringae, P2S.m: Pseudomonas putida-Serratia marcescens, B4P1: Pseudomonas cichorii-Bacillus thuringiensis, P2B4S.m: Pseudomonas putida-Bacillus thuringiensis-Serratia marcescens.

\subsubsection{Effect of PGPR Rhizobacteria on in Vitro Germination of Maize}

1) Disinfection and inoculation of maize seeds: The seeds were disinfected by soaking for two (02) minutes in a sodium hypochlorite solution $(0.024 \%)$ and then rinsed abundantly with sterile distilled water under vortex agitation [27]. 
The seed treated were immersed in the various suspensions of PGPR previously prepared for $30 \mathrm{~min}$ [28].

2) Germination of maize seed: After inoculation, twelve (12) seeds were dispersed equidistantly on a paper towel previously moistened with $10 \mathrm{ml}$ of sterile distilled water deposited in sterile square petri dishes of $11.8 \mathrm{~cm}$ side. Maize seeds were subsequently covered by another paper towel, watering with $10 \mathrm{ml}$ and the petridishes were incubated at $30^{\circ} \mathrm{C}$. For seven (07) days [29]. After 7 days, the number of germinated seeds was counted in order to determine the germination percentage corresponding to number of seed germinated seed/ number of seed set on germination [30]. The root and shoot length of individual seedling was measured and the vigor index was determined following the method of [31].

\subsubsection{Potty Test: Effects of PGPR on Growth of Maize Grown on Soil Ferruginous}

1) Seedlings, inoculation and maintenance of plants: The ferruginous soil used for the potty test was previously sifted and autoclaved twice at $121^{\circ} \mathrm{C}$ with 24 hour time interval for twenty minutes [32]. Pots were filled with $6 \mathrm{~kg}$ of soil and were watered to 2/9th of their maximum holding capacity (CMR) 24 hours prior to sowing [33]. After opening the hole in the centre of each pot, two (02) seeds were introduced in the hole and immediately inoculated with $10 \mathrm{ml}$ of suspension of each bacterial strain contain about $1 \times 10^{8} \mathrm{CFU} / \mathrm{ml}$ according the treatment, and the seed hole has been closed. The pot experiment was conducted in greenhouse condition (altitude $22 \mathrm{~m} ; 6^{\circ} 25^{\prime} \mathrm{N} ; 2^{\circ} 20^{\prime} \mathrm{E}$ ) at the University of Abomey Calavi, South Africa, Republic of Benin in 2017 (from june to july) with the temperature varying between $25.3^{\circ} \mathrm{C}$ (daily temperature) and $28.83^{\circ} \mathrm{C}$ (nocturnal temperature). On the 7 th days after seeding, the least vigorous of the two plants was thinned. Pots were watered at $1 / 9$ th of their maximum water retention capacity (CRM) every 48 hours after germination until 30 days.

\subsubsection{Chemical Analysis of the Substrate Used}

The chemical analyses of soil samples were carried out at the laboratory of Soil Sciences, water and Environment (LSSEE) of the National Institute of Agricultural Research of Benin (INRAB). These analyses consisted of $\mathrm{pH}$ measurement using an electrode $\mathrm{pH}$ meter in a soil/water ratio of $2 / 5(\mathrm{~g} / \mathrm{ml})[34]$ to the determination of the assimilative phosphorus using the Bray-1 method [35], Nitrogen [36] based on the KJEDATHL and potassium method [37] Also, the exchangeable bases (Ca, $\mathrm{Mg}, \mathrm{K}, \mathrm{Na}$ ) were determined by the [38].

\subsubsection{Data Collection for Growth and Yield Parameters}

Plant Heigth and collar diameter were measured from the 7th days after seeding (DAS) to up 30 DAS. The leaf area of the seedlings was calculated using the method described by [38] through the collection of the length measurement and the width of the last two leaves ligulate at the end of the test (30 JAS). In addition, dry matter (aerial and underground) was determined by weighing after drying in 
the oven at $70^{\circ} \mathrm{C}$. For 72 hours of fresh aerial biomass and fresh underground biomass.

\subsubsection{Determination of the $N, P, K$ Macro Nutrient Content of Maize Plants}

Dry (aerial and underground) biomasses were crushed to mortar and digested using the micro-Kjeldahl method and nitrogen $\mathrm{n}$ was determined by colorimetry [39], after mineralization of plant matter at $505^{\circ} \mathrm{C}$ for $16 \mathrm{~h}$ followed by dissolution of ash in amixture containing $15 \mathrm{ml} \mathrm{HClO}_{4}$ and $5 \mathrm{ml} \mathrm{HNO}_{3}$ as described by [40] potassium $\mathrm{K}$ and phosphorus $\mathrm{P}$ were determined respectively by emissions $\mathrm{N}$ in flame and by colorimetry [41].

\subsubsection{Statistical Analysis of Data}

The data collected were subjected to a two-factor ANOVA (repeats and treatments) statistical analysis after performing the normality and variance homogeneity test. The concentrations of nitrogen, phosphorus and potassium in the air dry matter and the levels of phosphorus and potassium in the underground dry matter did not verify these conditions. The Kruskal Wallis test was therefore carried out on the data of these variables. Evidence of significant differences between treatments was achieved using the student-Newman-Keuls test at the 5\% probability threshold. An ascending hierarchical classification (CHA) was performed on the average of the different parameters by treatment to group them into homogeneous classes. Finally, the principal component (PCA) analysis on the treatment averages allowed us to describe the links between the variables and to characterize each treatment group. These analyses were carried out in the software R version 3.4.3 assistant of the packages graphics, Factoextra and Facto MineR. The graph Pad software Prism version 7.00 allowed us to trace the graphs.

\section{Results}

\subsection{Germination}

Table 1 shows the effect of PGPR and their combination on germination parameters. Good germination (93.75\% to $100 \%$ ) of the seeds was observed on all treatments including the control with $S$. marcescens at the top. Seeds inoculated with $P$. cichorii, B. panthothenicus, and $S$. marcescens induced an improvement in seedling length up to $118.95 \%, 110.74 \%$ and $85.62 \%$ respectively, compared to non-inoculated seeds. For root lengths, the longest roots were obtained with seeds inoculated with $B$. panthothenicus followed by $S$. marcescens, which was an increase of $58.86 \%$ and $53.74 \%$ in comparison with uninoculated seeds. Strains of B. panthothenicus (76.64\%) and S. marcescens $(73.14 \%)$ were more efficient on the vigor index compared to controls. Analysis of the variance applied to the averages of the vigor index, seedling lengths, and maize roots showed a very highly significant difference $(\mathrm{P}<0.001)$ between the different treatments. 
Table 1. Effect of PGPR on germination parameters.

\begin{tabular}{|c|c|c|c|c|}
\hline Traitements & Germination rate & Root length $(\mathrm{cm})$ & Shoot length $(\mathrm{cm})$ & Vigor index \\
\hline CTL & $93.75 \pm 4.16^{\mathrm{a}}$ & $17.21 \pm 1.13^{\text {efg }}$ & $6.33 \pm 0.74^{\mathrm{h}}$ & $2206.87 \pm 294.6^{\mathrm{e}}$ \\
\hline B1 & $93.75 \pm 7.88^{\mathrm{a}}$ & $24 \pm 2.18^{\text {cde }}$ & $11.06 \pm 2.49^{\text {cdef }}$ & $3286.87 \pm 652.7^{\mathrm{cd}}$ \\
\hline B2 & $95.83 \pm 4.80^{\mathrm{a}}$ & $22.72 \pm 1.6^{\text {cdefg }}$ & $9.74 \pm 2.00^{\mathrm{fg}}$ & $3110.64 \pm 308.5^{\mathrm{d}}$ \\
\hline B3 & $93.75 \pm 4.16^{\mathrm{a}}$ & $22.56 \pm 1.18^{\operatorname{defg}}$ & $9.87 \pm 0.66^{\mathrm{efg}}$ & $3040.31 \pm 284.9^{c d}$ \\
\hline B4 & $93.75 \pm 4.16^{\mathrm{a}}$ & $23.35 \pm 2.01^{\text {cdef }}$ & $11.59 \pm 0.87^{\text {bcde }}$ & $3275.62 \pm 190.2^{\mathrm{cd}}$ \\
\hline B5 & $95.83 \pm 4.8^{\mathrm{a}}$ & $27.34 \pm 1.89^{\mathrm{a}}$ & $13.34 \pm 0.44^{\mathrm{ab}}$ & $3898.36 \pm 143.9^{a}$ \\
\hline P1 & $97.91 \pm 4,16^{\mathrm{a}}$ & $21.67 \pm 0.95^{\mathrm{fg}}$ & $13.86 \pm 0.78^{\mathrm{a}}$ & $3478.74 \pm 139.1^{\mathrm{bcd}}$ \\
\hline P2 & $97.91 \pm 4.16^{\mathrm{a}}$ & $23.19 \pm 1.24^{\text {cdef }}$ & $10.15 \pm 1.03^{\operatorname{defg}}$ & $3264.31 \pm 93.97^{\mathrm{d}}$ \\
\hline P3 & $97.91 \pm 4.16^{\mathrm{a}}$ & $23.00 \pm 1.30^{\text {cdef }}$ & $10.11 \pm 1.63^{\operatorname{defg}}$ & $3241.80 \pm 312.5^{\mathrm{cd}}$ \\
\hline S.m & $100 \pm 0^{\mathrm{a}}$ & $26.46 \pm 1.18^{\mathrm{ab}}$ & $11.75 \pm 0.70^{\mathrm{bcd}}$ & $3821 \pm 150^{\mathrm{ab}}$ \\
\hline В1B2B3B4 & $97.91 \pm 4.16^{\mathrm{a}}$ & $23.04 \pm 1.10^{\text {cdef }}$ & $10.26 \pm 0.20^{\operatorname{defg}}$ & $3260.40 \pm 59.46^{\mathrm{cd}}$ \\
\hline B4B5S.m & $100 \pm 0^{\mathrm{a}}$ & $20.76 \pm 2.06^{\mathrm{g}}$ & $12.24 \pm 1.36^{\mathrm{abc}}$ & $3300 \pm 329.5^{\mathrm{cd}}$ \\
\hline P1P2P3 & $97,91 \pm 4.16^{\mathrm{a}}$ & $24.76 \pm 0.49^{b c}$ & $11.20 \pm 0.36^{\text {cdef }}$ & $3520.84 \pm 162.5^{\mathrm{abc}}$ \\
\hline P2S.m & $100 \pm 0^{\mathrm{a}}$ & $22.94 \pm 1.78^{\text {cdef }}$ & $8.97 \pm 1.09^{\mathrm{g}}$ & $3191 \pm 202^{\mathrm{cd}}$ \\
\hline B4P1 & $95.83 \pm 4.8^{\mathrm{a}}$ & $22.85 \pm 0.8^{\text {cdefg }}$ & $10.34 \pm 1.28^{\mathrm{bcd}}$ & $3180.59 \pm 184.6^{\mathrm{cd}}$ \\
\hline B4P2S.m & $100 \pm 0^{\mathrm{a}}$ & $24.17 \pm 1.50^{\mathrm{cd}}$ & $10.52 \pm 1.49^{\text {cdefg }}$ & $3469 \pm 267.3^{\mathrm{bcd}}$ \\
\hline Probabilité & 0.3385 & 0.000 & 0.000 & 0.000 \\
\hline Signification & NS & $* * *$ & $* * *$ & $* * *$ \\
\hline
\end{tabular}

${ }^{* *}=\mathrm{P}<0.001$ (highly significant), NS $=\mathrm{P}>0.05$ (not significant), values indicate means, \pm indicate standards of calculated deviations of the four replicates. The averages followed by the same letter are not significantly different from the Newman-Keuls test at the 0.05 probability level. CTL: Control without bacteria, B1: Bacillus polymysa, B2: Bacillus anthracis, B3: Bacillus circulans, B4: Bacillus thuringiensis, B5: Bacillus panthothenicus, P1: Pseudomonas cichorii, P2: Pseudomonas putida, P3: Pseudomonas syringae, Sm: Serratia marcescens, B1B2B3B4B5: Bacillus polymysa-Bacillus anthracis-Bacillus circulans-Bacillus thuringiensis + Bacillus panthothenicus, B4B5Sm: Bacillus thuringiensis-Bacillus panthothenicus + Serratia marcescens, P1P2P3: Pseudomonas cichorii-Pseudomonas putida + Pseudomonas syringae, P2Sm: Pseudomonas putida-Serratia marcescens, B4P1: Pseudomonas cichorii-Bacillus thuringiensis, P2B4Sm: Pseudomonas putida-Bacillus thuringiensis-Serratia marcescens.

\subsection{Effects of PGPR on the Growth Parameters of Maize Plants in Greenhouse Conditions}

\subsubsection{Chemical Characteristics of Soil}

The assessment of experimental soil chemistry (Table 2) revealed that the organic matter rate was low $(0.1 \%)$ and that of nitrogen $(0.1 \%)$. The content $(6$, $91 \mathrm{ppm})$ of phosphorus is average in soil. The sum of the bases $(3.3 \mathrm{meq} / 100 \mathrm{~g}$ soil) and cation exchange capacity (6.06 meq) are low. The $\mathrm{pH}$ values ( $\mathrm{pH}$-water $=6.01$ and $\mathrm{pH}-\mathrm{KCl}=5.5)$ showed that the study soil was moderately acidic. These recorded chemical properties reflect a limited fertility of the study soil due to its low mineral reserves with a fairly pronounced phosphorus deficiency. This soil has been classified in the agroecology zone III (food cultivation area south of Borgou) with a low level of fertility [42] responsible for declining crops yields such as maize. 
Table 2. Chemical characteristic of the study soil.

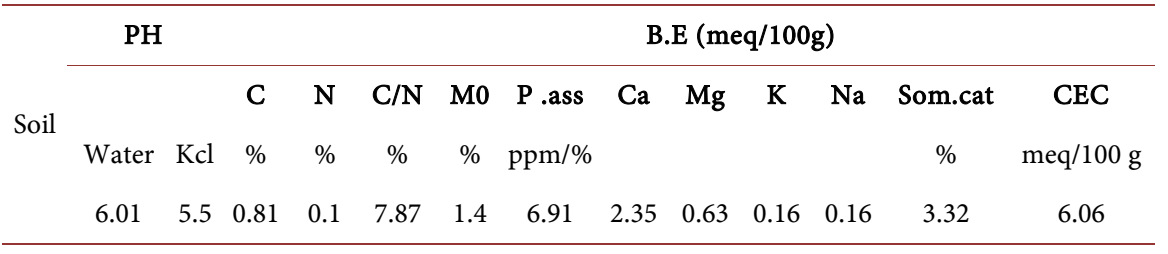

\subsubsection{Growth Parameters (Height, Collar Diameter and Leaf Area of Plants)}

From the analysis in Table 3, it is apparent that the bacterial strains tested have a very highly significant effect $(\mathrm{P}<0.001)$ on the height of the seedlings at 30th day after sowing. The maximum heights of the seedlings were induced by seedlings inoculated with $S$. marcescens, an increase of $58.83 \%$ in comparison with the control plants followed by plants treated with $P$. cichorii and $P$. putida, respectively, with increases of $53.91 \%$ and $45.64 \%$ compared to control plants. On the other hand, the effect expressed at the circumference of the seedling collar by the PGPR and their combination indicates that there is no significant difference $(P<0.05)$ between treatments. In contrast, inoculation of maize seeds by PGPR had a stimulating effect on the leaf area of the seedlings. The best leaf surfaces were obtained with the inoculation of $S$. marcescens followed by $P$. putida, a percentage improvement of $108.43 \%$ and $107.90 \%$, respectively, compared with the control plants.

\subsection{Effect of PGPR on Yield Parameters (Fresh Aboveground and Underground Biomass and Dry Matter)}

At the reading of Figure 1(a), the plants inoculated with $P$. putida followed by $S$. marcescens produced the most important fresh aerial biomass, with increases of $161.60 \%$ and $94.37 \%$ compared to controls. In fact, according to the results of the analysis of variance, a very highly significant difference $(\mathrm{P}<0.001)$ between the different treatments was noted. In addition, a similar improvement $(\mathrm{P}<$ 0.001) was also observed for some strains on the fresh underground biomass of seedlings. This is the case of $S$. marcescens, B. panthothenicus and $P$. cichorii, which induced an increase of the fresh underground biomass up to $59.16 \%$; $52.08 \%$ and $47.45 \%$, respectively compared with control plants. The lowest value of fresh underground biomass was recorded with plants treated with B. circulans. Rather, the analysis in Figure 1(b) indicates that the inoculation of PGPR and their combination has had a positive impact not only on air dry matter but also on the underground dry matter of plants. The highest significant values $(\mathrm{P}<$ 0.001 ) of air dry matter were obtained with $P$. putida treatments followed by $S$. marcescens, which induced an increase of $78.83 \%$ and $78.09 \%$ respectively. For the underground dry matter, the best productions were recorded at the " $P$. putida-S. marcescens" combination followed by " $B$. thuringiensis- $P$. cichorii". The underground dry matter developed with the inoculation of $P$. syringae experienced an increase of $57 \%$ over the control plants. 
Table 3. Effect of PGPR on growth parameters.

\begin{tabular}{|c|c|c|c|c|c|c|}
\hline \multirow{2}{*}{ Traitements } & \multicolumn{2}{|c|}{ Height $(\mathrm{cm})$} & \multicolumn{2}{|c|}{ Circumference $(\mathrm{cm})$} & \multicolumn{2}{|c|}{ Leaf Area $\left(\mathrm{cm}^{2}\right)$} \\
\hline & $\mathrm{m}$ & $\mathrm{cv}$ & $\mathrm{m}$ & $\mathrm{cv}$ & $\mathrm{m}$ & $\mathrm{cv}$ \\
\hline CTL & $11.37^{\mathrm{f}}$ & 12.82 & $2.40^{\mathrm{a}}$ & 7.53 & $55.13^{\mathrm{d}}$ & 8.65 \\
\hline B1 & $13.73^{\mathrm{de}}$ & 4.85 & $2.93^{\mathrm{a}}$ & 12.37 & $73.49^{c}$ & 3.52 \\
\hline B2 & $13.5^{\mathrm{def}}$ & 7.80 & $2.61^{\mathrm{a}}$ & 6.93 & $59.82^{\mathrm{d}}$ & 13.15 \\
\hline B3 & $11.83^{\mathrm{ef}}$ & 4.65 & $2.51^{\mathrm{a}}$ & 0.00 & $59.46^{\mathrm{d}}$ & 9.40 \\
\hline B4 & $14.56^{\mathrm{cd}}$ & 10.33 & $3.14^{\mathrm{a}}$ & 10.00 & $81.64^{\mathrm{bc}}$ & 6.35 \\
\hline B5 & $14.86^{\mathrm{cd}}$ & 5.44 & $2.82^{\mathrm{a}}$ & 19.25 & $94.30^{\mathrm{b}}$ & 3.64 \\
\hline P1 & $17.53^{\mathrm{ab}}$ & 2.63 & $3.24^{\mathrm{a}}$ & 22.35 & $85.47^{\mathrm{bc}}$ & 15.38 \\
\hline P2 & $16.56^{\mathrm{abc}}$ & 7.55 & $3.45^{\mathrm{a}}$ & 18.18 & $114.62^{\mathrm{a}}$ & 1.45 \\
\hline P3 & $16.46^{\mathrm{abc}}$ & 2.45 & $3.24^{\mathrm{a}}$ & 14.78 & $92.10^{\mathrm{b}}$ & 12.63 \\
\hline S.m & $18.06^{\mathrm{a}}$ & 2.84 & $3.24^{\mathrm{a}}$ & 27.94 & $114.91^{\mathrm{a}}$ & 1.36 \\
\hline B1B2B3B4B5 & $14.63^{\mathrm{cd}}$ & 7.50 & $2.82^{\mathrm{a}}$ & 0.00 & $90.38^{\mathrm{bc}}$ & 12.28 \\
\hline B4B5S.m & $13.5 \mathrm{~d}^{\mathrm{ef}}$ & 11.11 & $2.66^{\mathrm{a}}$ & 17.65 & $93.78^{\mathrm{b}}$ & 7.66 \\
\hline P1P2P3 & $14.8^{\mathrm{cd}}$ & 2.44 & $2.82^{\mathrm{a}}$ & 11.11 & $79.57^{\mathrm{bc}}$ & 4.12 \\
\hline P2S.m & $14.73^{\mathrm{cd}}$ & 4.36 & $2.82^{\mathrm{a}}$ & 2.83 & $87.27^{b c}$ & 6.70 \\
\hline B4P1 & $15.6 \mathrm{~b}^{\mathrm{cd}}$ & 2.56 & $3.14^{\mathrm{a}}$ & 20.00 & $97.73^{\mathrm{b}}$ & 4.10 \\
\hline P2B4S.m & $14 \mathrm{~cd}^{\mathrm{e}}$ & 10.57 & $2.82^{\mathrm{a}}$ & 2.83 & $88.28^{\mathrm{bc}}$ & 3.75 \\
\hline Probability & \multicolumn{2}{|c|}{$<0.001$} & \multicolumn{2}{|c|}{0.578} & \multicolumn{2}{|c|}{$3.721 \mathrm{e}-12$} \\
\hline Signification & \multicolumn{2}{|c|}{$* * *$} & \multicolumn{2}{|c|}{ NS } & \multicolumn{2}{|c|}{$* * *$} \\
\hline
\end{tabular}

$\mathrm{NS}=\mathrm{P}>0.05$ (not significant). $\mathrm{m}=$ means and $\mathrm{cv}=$ coefficient of variation. The averages followed by the same letter are not significantly different by the Newman-Keuls test at the 0.05 probability level.

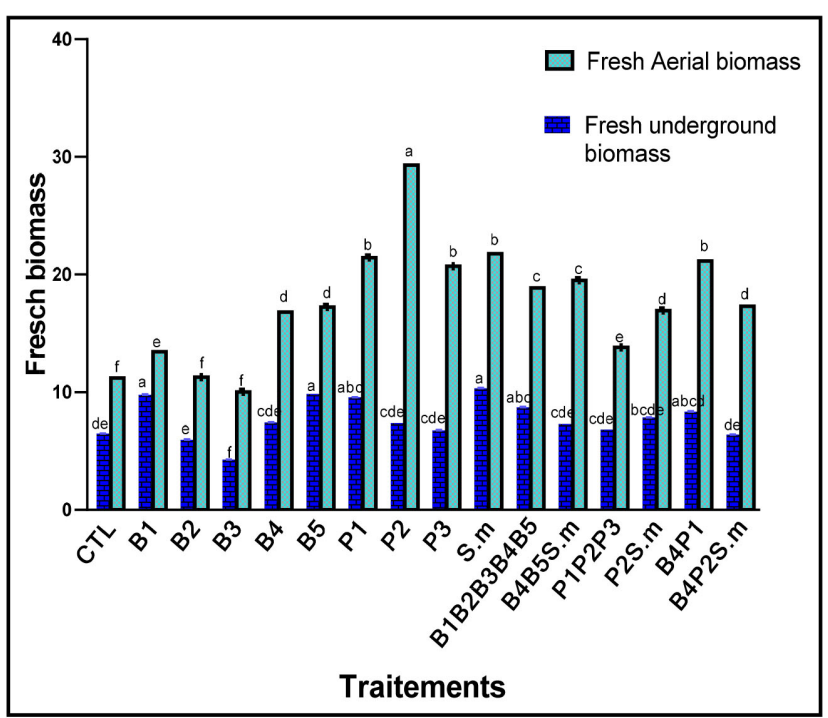

(a)

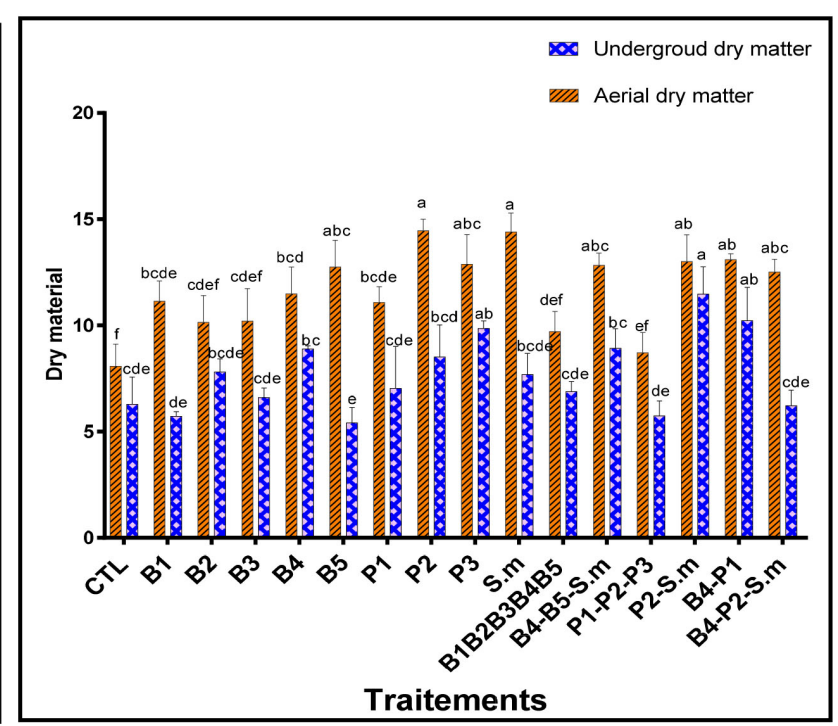

(b)

Figure 1. Fresh biomass of corn plants based on different treatments (a) Dry matter produced by maize plants according to different treatments (b). CTL: Control without bacteria, Bacillus polymysa, B2: Bacillus anthracis, B3: Bacillus circulans, B4: Bacillus thuringiensis, B5: Bacillus panthothenicus, P1: Pseudomonas cichori, P2: Pseudomonas putida, P3: Pseudomonas syringae, Sm: Serratia marcescens, B1B2B3B4B5: Bacillus polymysa-Bacillus anthracis-Bacillus circulans-Bacillus thuringiensis-Bacillus panthothenicus, B4B5Sm: Bacillus thuringiensis-Bacillus Panthothenicus-Serratia marcescens, P1P2P3: Pseudomonas cichorii-Pseudomonas putida-Pseudomonas syringae, P2Sm: Pseudomonas putida-Serratia marcescens, B4P1: Pseudomonas cichorii-Bacillus thuringiensis, P2B4Sm: Pseudomonas putida-Bacillus thuringiensis-Serratia marcescens. 


\subsection{Correlation between Growth Parameters and Yield Parameters}

Figure 2 shows the dendrogram of the Hierarchical Ascending classification $(\mathrm{ACH})$ of the treatments according to the variables studied. The analysis of this dendrogram shows that the 16 treatments were divided into four (4) groups. Group 1 consists of B. polymysa, B. anthracis, and P. cichorii-P. putida-P. syringae. Group 2 brings together B. panthothenicus, B. thuringiensis-P. cichorii; $B$. thuringiensis-B. panthothenicus-S. marcescens, P. syringae, P.cichorii; P. putida-S. marcescens; $B$. polymysa polymysa-B. anthracis- $B$. circulans- $B$. thuringiensis-B. Panthothenicus and B. thuringiensis-P. cichorii-S. marcescens. Group 3 includes the witness; $B$. anthracis and $B$. circulans. The treatments $P$. putida and $S$. marcescens form Group 4.

Figures 3(a) and Figures 3(b) represent the projection on the factorial plane (Dim1 and Dim2) of the data of the variables studied in greenhouse maize plants. The two axes (Dim1 and Dim2) represent $83.16 \%$ of the total variance, which is sufficient to guarantee a precision of interpretation for the identification of the main parameters and the discriminant treatments. Variables such as air dry matter (MSA), leaf area (S. Folliaire), fresh aerial biomass (BAF), circumference and height are strongly represented on the first main component (Dim1) while the underground dry matter (MSS) and the fresh underground biomass (BSF) are represented on the second main component (Dim2). With regard to the behaviour of the treatments against the different variables evaluated, four distinct major groups emerge:

- Group 4 includes strains of PGPR with significantly improved the height, circumference, fresh aerial biomass (BAF), dry underground biomass (BSF), material dry air (MSA), and leaf area of the maize plants. This group includes

$P$. putida and $S$. marcescens which are well represented on the first axis (Dim1).

- Group 3 located opposite the axes of variables includes the stem B. circulans, $B$. anthracis and the witness with the lowest values of all the evaluated parameters.

- Group 2 brings together eight treatments that stand out particularly because of their performance at the level of the underground dry matter (MSS) developed by corn plants with $P$. putida-S. marcescens at the top.

- Group 1 includes treatments such as: $P$. cichorii-P. putida-P. syringae, B. polymysa and $B$. thuringiensis having mainly negatively as corn plants underground dry matter (MSS) evidenced by their position on the Dim1 axis by report to this variable.

\subsection{Effect of PGPR on the Content of Macronutrients in the Dry Matter}

With the exception of the content of nitrogen, the statistical analysis of the results illustrated by Table 4 indicated a significant effect of the inoculation of the seeds by PGPR on the content of phosphorus and potassium in aerial biomass of corn plants $(\mathrm{P}<0.05)$ compared with controls. Indeed, aerial biomass of plants 


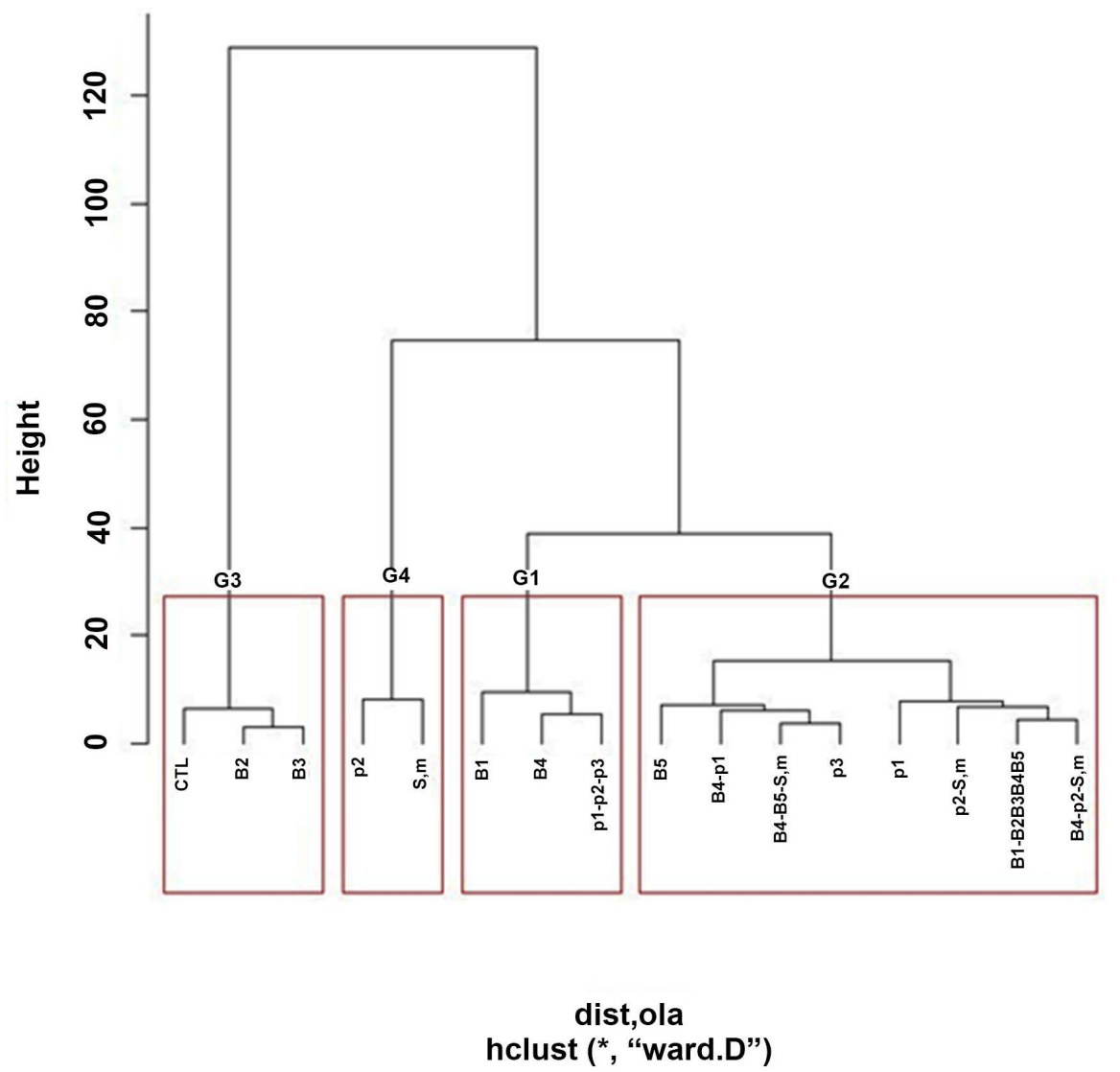

Figure 2. Dendrogram of the hierarchical ascending classification $(\mathrm{ACH})$ of the treatments according to the variables studied.

handled by $S$. marcescens have presented the strongest levels in phosphorus and potassium. These values exceed respectively $80 \%$ and $11.29 \%$ those obtained at the level of the plants not inoculated. It is the same for plants under influence of $P$. putida where an increase of $15 \%$ and $80 \%$ respectively of the potassium and phosphorus content was recorded in comparison with plants witnesses. Phosphorus in the underground biomass of plants has been significantly improved ( $P$ $<0.05)$ with inoculation in comparison with plants witnesses. The highest average phosphorus $(0.189 \pm 0.01)$ has been registered with the combination $S$. marcescens-P. putida. On the other hand, nosignificant difference was observed on the rate of nitrogen and potassium between treatments. However, the best nitrogen levels $(2.04 \pm 0.39)$ and potassium $(2.38 \pm 0.72)$ were obtained with the inoculated plants.

\section{Discussion}

\subsection{Germination Test}

The results obtained in vitro show that treatment of the seeds of corn with PGPR strains has impacted positively the germinal parameters of the maize seeds. Indeed, good (93.75\% to $100 \%)$ germination of the seeds was noted whether at the level of the inoculated seed as witnesses thus attesting the good quality of the 


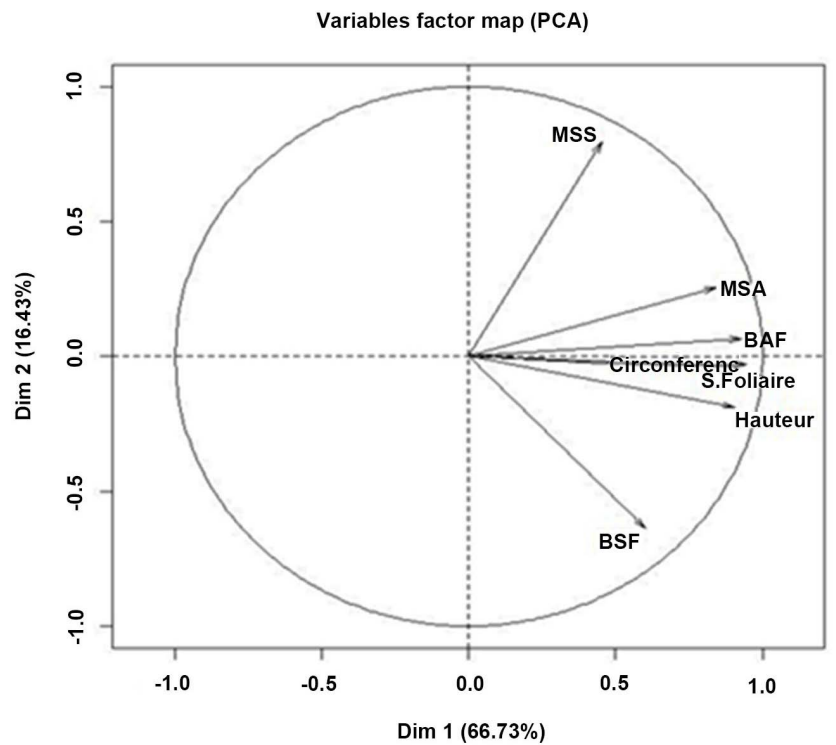

(a)

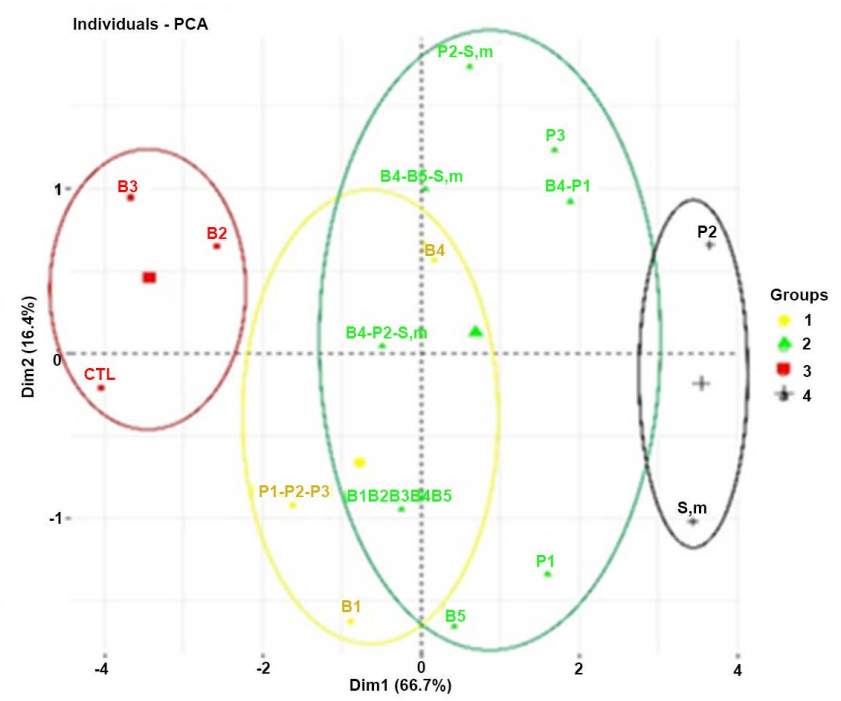

(b)

Figures 3. Factorial projection Dim1 (a) and Dim2 (b) of the data of the variables studied on greenhouse maize plants. MSS $=$ dry underground material, MSA = aerial underground material, $\mathrm{BAF}=$ cool aboveground biomass, $\mathrm{S}=$ surface, BSF $=$ cool underground biomass. CTL: Control without bacteria, Bacillus polymysa, B2: Bacillus anthracis, B3: Bacillus circulans, B4: Bacillus thuringiensis, B5: Bacillus panthothenicus, P1: Pseudomonas cichori, P2: Pseudomonas putida, P3: Pseudomonas syringae, Sm: Serratia marcescens, B1B2B3B4B5: Bacillus polymysa-Bacillus anthracis-Bacillus circulans-Bacillus thuringiensis-Bacillus panthothenicus, B4B5Sm: Bacillus thuringiensis-Bacillus panthothenicus-Serratia marcescens, P1P2P3: Pseudomonas cichorii-Pseudomonas putida-Pseudomonas syringae, P2Sm: Pseudomonas putida-Serratia marcescens, B4P1: Pseudomonas cichorii-Bacillus thuringiensis, P2B4Sm: Pseudomonas putida-Bacillus thuringiensis-Serratia marcescens.

seeds used in our study. However, no significant differences $(\mathrm{P}>0.05)$ were observed between treatments. Note even when that seeds inoculated with $S$. marcescens followed by some combinations of which $P$. putida-S. marcescens have been best $(100 \%)$ in comparison with the witnesses seeds germination rates. These observations are consistent with the work of [43] who got $100 \%$ germination after inoculation seeds of maize with $P$. putida. Similarly, [44] reported a germination rate of $96 \%$ in Egypt with the inoculation of $S$. marcescens on maize seeds. This positive effect of PGPR on the germination of seeds would be linked to the bacterial ability to produce or modify plant hormones including gibberellins which play a key role in germination [45] [46].

All of the maize seeds treated with the PGPR showed highly significant improvements $(\mathrm{P}<0.001)$ about the length of the seedling and roots. Indeed, values the highest length of seedlings were obtained with the application of $P$. $c i$ chorii followed by $B$. panthothenicus by the respective increases of $118.95 \%$ and $110.74 \%$ compared to controls. The seeds treated with $B$. panthothenicus and $S$. marcescens stimulated a significant elongation of the roots, which exceeded $58.86 \%$ and $53.74 \%$ relative to the control, respectively. These improvements in our study are confirmed by the work of [47]. These authors showed that the strains of Bacillus sp., Serratia sp. SY 5 have led to a significant increase in the length of the seedlings and roots of maize. 
Table 4. Effect of PGPR on the content of macronutrients in dry matter.

\begin{tabular}{|c|c|c|c|c|c|c|}
\hline \multirow{2}{*}{ Treatments } & \multicolumn{3}{|c|}{ Aerial dry matter } & \multicolumn{3}{|c|}{ Underground dry matter } \\
\hline & $\% \mathrm{~N}$ & $\% \mathrm{P}$ & $\% \mathrm{~K}$ & $\% \mathrm{~N}$ & $\% \mathrm{P}$ & $\% \mathrm{~K}$ \\
\hline CTL & $2.63 \pm 0.70^{\mathrm{a}}$ & $0.15 \pm 0.0^{\text {cd }}$ & $4.16 \pm 0.02^{\mathrm{def}}$ & $1.63 \pm 0.24^{\mathrm{a}}$ & $0.181 \pm 0.05^{\mathrm{abc}}$ & $1.80 \pm 0.19^{\mathrm{a}}$ \\
\hline B1 & $2.86 \pm 0.55^{\mathrm{a}}$ & $0.13 \pm 0.00^{\mathrm{cd}}$ & $3.88 \pm 0.11^{\mathrm{ef}}$ & $1.67 \pm 0.26^{\mathrm{a}}$ & $0.120 \pm 0.01^{\mathrm{de}}$ & $1.80 \pm 0.08^{\mathrm{a}}$ \\
\hline B2 & $3.06 \pm 0.91^{\mathrm{a}}$ & $0.18 \pm 0.05^{\mathrm{bcd}}$ & $4.76 \pm 0.25^{\mathrm{ab}}$ & $1.46 \pm 0.08^{\mathrm{a}}$ & $0.180 \pm 0.01^{\mathrm{ab}}$ & $1.78 \pm 0.20^{\mathrm{a}}$ \\
\hline B3 & $2.93 \pm 0.85^{\mathrm{a}}$ & $0.11 \pm 0.01^{\mathrm{d}}$ & $2.83 \pm 0.10^{f}$ & $1.98 \pm 0.18^{\mathrm{a}}$ & $0.112 \pm 0.01^{\mathrm{e}}$ & $1.79 \pm 0.19^{\mathrm{a}}$ \\
\hline B4 & $3.10 \pm 1.15^{\mathrm{a}}$ & $0.18 \pm 0.05^{\mathrm{bcd}}$ & $4.30 \pm 0.50^{\mathrm{bcde}}$ & $1.60 \pm 0.26^{\mathrm{a}}$ & $0.137 \pm 0.03^{\text {cde }}$ & $1.74 \pm 0.15^{\mathrm{a}}$ \\
\hline B5 & $3.32 \pm 1.05^{\mathrm{a}}$ & $0.25 \pm 0.04^{\mathrm{ab}}$ & $4.06 \pm 0.85^{\text {cdef }}$ & $1.86 \pm 0.12^{\mathrm{a}}$ & $0.168 \pm 0.00^{\text {cde }}$ & $2.38 \pm 0.72^{\mathrm{a}}$ \\
\hline P1 & $3.23 \pm 0.78^{\mathrm{a}}$ & $0.23 \pm 0.01^{\mathrm{ab}}$ & $4.68 \pm 0.25^{\mathrm{abc}}$ & $1.90 \pm 0.17^{\mathrm{a}}$ & $0,159 \pm 0.00^{\mathrm{abc}}$ & $1.67 \pm 0.25^{\mathrm{a}}$ \\
\hline P2 & $3.31 \pm 0.91^{\mathrm{a}}$ & $0.27 \pm 0.01^{\mathrm{a}}$ & $4.81 \pm 0.20^{\mathrm{a}}$ & $1.79 \pm 0.31^{\mathrm{a}}$ & $0.138 \pm 0.00^{\text {cde }}$ & $1.99 \pm 0.52^{\mathrm{a}}$ \\
\hline P3 & $3.07 \pm 0.88^{\mathrm{a}}$ & $0.25 \pm 0.05^{\mathrm{ab}}$ & $4.44 \pm 0.26^{\mathrm{abcd}}$ & $1.84 \pm 0.12^{\mathrm{a}}$ & $0.140 \pm 0.03^{\text {cde }}$ & $1.75 \pm 0.18^{\mathrm{a}}$ \\
\hline S.m & $3.33 \pm 0.95^{\mathrm{a}}$ & $0.27 \pm 0.01^{\mathrm{a}}$ & $4.63 \pm 0.30^{\mathrm{abcd}}$ & $1.98 \pm 0.10^{\mathrm{a}}$ & $0.156 \pm 0.01^{\mathrm{abcd}}$ & $1.32 \pm 0.08^{\mathrm{a}}$ \\
\hline B1B2B3B4B5 & $3.45 \pm 0,70^{\mathrm{a}}$ & $0.27 \pm 0.01^{\mathrm{a}}$ & $4.75 \pm 0.24^{\mathrm{ab}}$ & $2.04 \pm 0.39^{\mathrm{a}}$ & $0.149 \pm 0.00^{\mathrm{abcd}}$ & $1.75 \pm 0.26^{\mathrm{a}}$ \\
\hline B4B5S.m & $3.25 \pm 0.89^{\mathrm{a}}$ & $0.27 \pm 0.01^{\mathrm{a}}$ & $4.34 \pm 0.22^{\text {bcde }}$ & $1.93 \pm 0.35^{\mathrm{a}}$ & $0.141 \pm 0.01^{\text {bcde }}$ & $1.83 \pm 0.05^{\mathrm{a}}$ \\
\hline P1P2P3 & $3.24 \pm 0.60^{\mathrm{a}}$ & $0.19 \pm 0.03^{\mathrm{bcd}}$ & $4.44 \pm 0.26^{\text {abcde }}$ & $1.82 \pm 0.22^{\mathrm{a}}$ & $0.133 \pm 0.01^{\text {cde }}$ & $1.79 \pm 0.09^{\mathrm{a}}$ \\
\hline P2S.m & $2.83 \pm 1.12^{\mathrm{a}}$ & $0.21 \pm 0.09^{\mathrm{abc}}$ & $4.32 \pm 0.37^{\text {bcde }}$ & $1.40 \pm 0.26^{\mathrm{a}}$ & $0.189 \pm 0.01^{\mathrm{a}}$ & $1.46 \pm 0.30^{\mathrm{a}}$ \\
\hline B4P1 & $3,16 \pm 1.00^{\mathrm{a}}$ & $0.26 \pm 0.01^{\mathrm{ab}}$ & $4.33 \pm 0.38^{\text {bcde }}$ & $1.64 \pm 0.08^{\mathrm{a}}$ & $0.181 \pm 0.05^{\mathrm{cde}}$ & $1.24 \pm 0.15^{\mathrm{a}}$ \\
\hline P2B4S.m & $3.22 \pm 0.54^{\mathrm{a}}$ & $0.22 \pm 0.01^{\mathrm{abc}}$ & $4.23 \pm 0.43^{\text {bcde }}$ & $2.03 \pm 0.04^{\mathrm{a}}$ & $0.184 \pm 0.05^{\mathrm{abc}}$ & $1.93 \pm 0.02^{\mathrm{a}}$ \\
\hline P-value & 0.955 & 0.0186 & 0.0233 & 0.059 & 0.036 & 0.089 \\
\hline Significance & NS & $* *$ & $* *$ & NS & ** & NS \\
\hline
\end{tabular}

NS $=\mathrm{P}>0.05$ (not significant). Value: mean \pm standard deviation, ${ }^{* *}$ : significant difference $(\mathrm{P}<0.05)$, the means followed by the same letter are not significantly different according to the Newman-Keuls test at $\mathrm{P}<0.05$. CTL: Control without bacteria, Bacillus polymysa, B2: Bacillus anthracis, B3: Bacillus circulans, B4: Bacillus thuringiensis, B5: Bacillus panthothenicus, P1: Pseudomonas cichori, P2: Pseudomonas putida, P3: Pseudomonas syringae, $\mathrm{Sm}$ : Serratia marcescens, B1B2B3B4B5: Bacillus polymysa-Bacillus anthracis-Bacillus circulans-Bacillus thuringiensis-Bacillus panthothenicus, B4B5Sm: Bacillus thuringiensis-Bacillus panthothenicus-Serratia marcescens, P1P2P3: Pseudomonas cichorii-Pseudomonas putida-Pseudomonas syringae, P2Sm: Pseudomonas putida-Serratia marcescens, B4P1: Pseudomonas cichorii-Bacillus thuringiensis, P2B4Sm: Pseudomonas putida-Bacillus thuringiensis-Serratia marcescens.

The effectiveness of the strains of $S$. marcescens, B. panthothenicus, P. cichorii observed in our study can be attributed to the ability of these isolates to produce the acid indole Acetic (AIA), a hormone that positively affects the growth and development of roots thus increasing absorption of nutrients [48] [49]. In comparison to the witness's seeds, all treatments have led to a significant improvement of the vigor index (Table 1). The best vigor index has been achieved on the seeds inoculated with $B$. panthothenicus, followed by $S$. marcescens. These results are similar to those of [50] who observed a significant increase in the length of the roots, seedling and vigor index with strains of Pseudomonas spp., Bacillus spp. after inoculation of these strains on maize in South Africa. Moreover, the results obtained in our study corroborate those [51] [52]. These authors reported that inoculation of spinach (Spinacia oleracea $L$.) and wheat by the rhizobacteria increases germinative parameters such as the length of the seedlings, the length 
of the roots and the vigor index during the germination period.

\subsection{Test in Greenhouse Condition}

The importance of PGPR strains on crops has been highlighted by [53] that corn plants inoculated by Actinomycete sp. $\mathrm{H} 7$ have recorded a significant increase up to $19.3 \%$ in height growth compared to the witnesses. In our study, the same trends were noted for the treatments $S$. marcescens; P. cichorii, and P. putida at the height of the plants level. Indeed, inoculation of these strains has led to a considerable improvement of the plant height varying from $44.76 \%$ to $58.83 \%$ in comparison to the winesses plants. These results resemble the $45 \%$ achieved by [54] in Argentina on the height of corn plants inoculated with Pseudomonas tolaasii IEXb. Also, all strains tested in this study proved to be very effective on leaf area of plants. Plants inoculated with $S$. marcescens had the highest leave followed by those treated by $P$. putida. These values exceed respectively $108.43 \%$ and $107.09 \%$ the average value obtained at the level of the non-inoculated control. These results are similar to those of [55] who reported the effectiveness of $S$. marcescens TRS- 1 on the increase of the height and aerial biomass of tea plants. Devi et al., [56] reported that the application of $S$. marcescens AL2-16 induces a better increase in leaf area, roots length, seedlings length, and dry weight of the fresh aerial biomass on Achyranthes aspera plants.

The higher aerial biomass was observed with the plants treated with $P$. putida and $S$. marcescens either respective increases of 161.60 and $94.37 \%$ compared to the control. On the underground biomass, best results were incurred with the inoculation of $S$. marcescens (59.16\%) followed by B. panthetonicus $(52.08 \%)$. The results achieved with the effect of the strain $S$. marcescens on biomass of the plants are in agreement with those [57] to the Brazil. These authors reported that inoculation of $S$. marcescens UENF-22GI (SMU) on corn has significantly increased the aerial biomass fresh and underground biomass fresh with a percentage of $64 \%$ and $80 \%$, respectively, compared to the plants improvement witnesses collected 10 after days of experience in controlled condition. The PGPR performance observed on aerial and underground plant biomass was related to their production capacity of growth, in particular the auxins and gibberellins the hormones. These hormones are known to induce an increase in root hairs and the growth of aerial parts [58].

As for the rate of the material dry air and underground developed by corn plants, the largest aerial dry matter production were recorded by plants treated with $P$. putida (78.83\%) followed by $S$. marcescens $(78.09 \%)$. Their combination has led to the largest underground dry matter $(82.64 \%)$. This rate would be due to the synergistic effect of combined two strains. Our results are similar to those of [59] who have obtained a significant increase of the dry biomass of plants respectively $99 \%$ and $94 \%$ compared to the control with the inoculation of Serratia marcescens sp. EB 67 and Pseudomonas sp. CDB 35 on corn. The production of phytohormone and other metabolites by the rhizobacteria is one of the most 
important factors in the promotion of the growth of plants. Agbodjato et al., [60] have recently highlighted the ability of the majority of the strains tested in our study to solubilize the inorganic phosphate and produce metabolites of agricultural interest such as acid indole acetic (AIA). The positive effects of the inoculation on the parameters evaluated in our study would be so related to the ability of strains of PGPR particulary $S$. marcescens, $P$. putida, and $P$. cichorii to produce the AIA, to solubilize phosphate or a conjunction of the two mechanisms. Mezaache [61] explains that the rhizobacteria producing AIA are known for their ability to increase growth and the length of the roots. This effect results in a greater root surface and accessibility for most nutrients for the plant. Our results are related to these observations because the maize plants inoculated with the rhizobacteria $P$. putida, S. marcescens (Table 4) having given biomass yields the highest underground are those who have potassium and phosphorus content the significantly higher. Similar increases in absorption of the macronutrients include nitrogen and phosphorus have been reported in the host plant after inoculation of wheat grain by $S$. marcescens [62]. These observations have also been confirmed by [63] [64].

In our study, the improvement of nutritional status at the level of the inoculated plants would result from a better accumulation of dry matter in the aerial part of the plant maize. Tarafdar et al., [65] explained the increase absorption of phosphorus, nitrogen, potassium, as well as other micronutrients by significant dry matter production in barley plants inoculated with the PGPR. Results for nutritional status obtained are in favour of a sustainable and environment-friendly agriculture. Indeed, the growth and the yield of plants are determined by the availability of some specific nutrients essential for the completion of their life cycle [66]. That is why the application of these essential nutrients (nitrogen, phosphorus and potassium) plants in the form of chemical fertilizers is part of intensive agriculture. Adjanohoun et al., [67] attributed the improvement of yields of corn achieved at the level of the plants inoculated with $P$. fluorescens, $P$. putida and A. lipoferum by increased absorption of nitrogen and potassium.

\subsection{Conclusion}

The results of the present study showed the beneficial role of PGPR inoculation on maize seed germination and seedling growth under laboratory and greenhouse conditions. For the majority of the evaluated parameters, the rhizobacteria $S$. marcescens, $P$. putida, and P. cichorii are most effective among those in the study. Furthermore, treatment of seeds with $S$. marcescens, and $P$. putida have led to better improvement in the nutritional status of plants including the content in phosphorous and potassium in aerial biomass of corn with a percentage plants improvement between $11.29 \%$ and $80 \%$ compared to plants not inoculated. These results are very interesting, and thus leave the possibility to exploit all of the strains selected in future experimental studies in order to produce some 
biofertilizers.

\section{Acknowledgements}

The authors thank the "Centre National de Spécialisation sur le Maïs (CNS-Maïs), the National Fund for scientific research and Innovation Technology (FNRSIT) for theit financial supports.

\section{Conflicts of Interest}

The authors declare no conflicts of interest regarding the publication of this paper.

\section{References}

[1] Ahmadi, N., Chantereau, J., Hekimian Le Thève, C., Marchand, J.L. and Ouendeba, B (2002) The Cereals. In: Memento of Agriculture, CIRAD-GRET, 780-792

[2] Cairns, J.E., Probe, K., Zaidi, P.H., Verhulst, N., Mahuku, G., Babu, R., Nair, S., Das, B., Govaerts, B. and Vinayan, M. (2012) Maize Production in a Changing Climate: Impacts, Adaptation, and Mitigation Strategies. Advances in Agronomy, 114, 1-58.

[3] Toléba, S.M., Biaou, G., Saïdou, A. and Zannou, A. (2015) Functioning of the Maize Sector in Benin. CBRST Papers, Vol. 1, Cotonou, 73-35-73.

[4] WAAPP/CNS-Corn (2012) Ratings Agronomic and Socio-Economic Systems of maize Production in the Agroecological Zones of Benin. Research Project Document, $62 \mathrm{p}$.

[5] INSAE (2010) Interim Results of the Rgph 4. Cotonou.

[6] WFP (2014) Global Analysis of Vulnerability, Food Security and Nutrition (AGVSAN).

[7] USDA (2017). https://quickstats.nass.usda.gov/

[8] Azontondé, A.H., Igué, A.M. and Dagbenonbakin, G. (2010) Benin Soil Fertility Map by Agroecological Zone of Benin. Final Report, Benin.

[9] MAEP (2017) MAEP Plan Stratégique de Développement du Secteur Agricole (PSDSA) 2025 et Plan National d'Investissements Agricoles et de Sécurité Alimentaire et Nutritionnelle PNIASAN 2017-2021. Cotonou.

[10] Alamri, R., Ben, A., Ben, H.A. and Labidi, S. (2016) Installation of a Biofertilizer Production unit. Seminar Report II, National Agronomic Institute of Tunisia. http://www.memoireonline.com/01/16/9399

[11] Alalaoui, A.C. (2007) Mineral Fertilization of Crops: Major Nutrients (Nitrogen, Potassium and Phosphorus). Monthly Bulletin of Information and Liaison, 155, 1-4.

[12] Okon, Y. and Hadar, Y. (1987) Microbial Inoculants as Crop-Yield Enhancers. Critical Reviews in Biotechnology, 6, 61-85. https://doi.org/10.3109/07388558709086985

[13] Timmusk, S., Paalme, V., Pavlicek, T., Bergquist, J., Vangala, A., Danilas, T. and Nevo, E. (2011) Bacterial Distribution in the Rhizosphere of wild Barley under Contrasting Microclimates. PLoS ONE, 6, e17968.

[14] Kumar, V.K., Reddy, M.S., Kloepper, J.W., Lawrence, K.S., Zhou, X.G., Groth, D.E., Zhang, S., Sudhakara, R.R., Wang, Q., Raju, M.R.B., Krishnam, R., Dilantha, F.W.G., Sudini, H., Du, B. and Miller, M.E. (2011) Commercial Potential of Microbial Inoculants for Sheath Blight Management and Yield Enhancement of Rice. In: 
Maheshwari, D.K., Ed., Bacteria in Agrobiology: Crop Ecosystems, Springer, Berlin, 237-264.

[15] Ma, Y., Oliveira, R.S., Freitas, H. and Zhang, C. (2016) Biochemical and Molecular Mechanisms of Plant-Microbe-782 Metal Interactions: Relevance for Phytoremediation. Frontiers in Plant Science, 7, 918. https://doi.org/10.3389/fpls.2016.00918

[16] Biswas, J.C., Ladha, J.K. and Dazzo, F.B. (2000) Rhizobia Inoculation Improves Nutrient Uptake and Growth of Lowland Rice. Soil Science Society of America Journal, No. 64, 1644-1650. https://doi.org/10.2136/sssaj2000.6451644x

[17] Mehrvarz, S., Chaichi, M.R. amd Alikhani, H.A. (2008) Effects of Phosphate Solubilizing Microorganisms and Phosphorus Chemical Fertilizers on Yield and Yield Components (Hordum vulgare L). American-Eurasian Journal of Agricultural Environmental Sciences, 3, 822-828.

[18] Majeed, A., Abbasi, M.K., Hameed, S. and Imran, N. (2015) Isolation and Characterization of Plant Growth Promoting Rhizobacteria from Wheat Hizo-Sphere and Their Effect on Plant Growth Promoting. Frontiers in Microbiology, 6, 198. https://doi.org/10.3389/fmicb.2015.00198

[19] Cakamackci, R., Dönmez, M.F. and Erdogan, Ü. (2007) The Effect of Plant Growth Promotes Rhizobacteria on Barely Seedling Growth, Nutrient Uptake, Sum Soil Properties, and Bacterial Counts. Turkish Journal of Agriculture and Forestry, 31, 189-199.

[20] Agbodjato, N.A., Noumavo, P.A., Adjanohoun, A., Agbessi, L. and Baba-Moussa, L. (2016) Synergistic Effects of Plant Growth Promoting Rhizobacteria and Chitosan in Vitro Germination, Greenhouse Growth, and Nutrient Uptake of Maize (Zea mays L.). Biotechnology Research International, 2016, Article ID: 7830182. https://doi.org/10.1155/2016/7830182

[21] Yallou, C.G., Aihou, K., Adjanohoun, A., Baco, M.N., Sanni, O.A. and Amadou, L. (2010) Répertoire des Variétés de Maïs Vulgarisées au Bénin: Document Technique d'Information et de vulgarisation. Dépôt légal $\mathrm{N}^{\circ} 4920$, 4e Trimestre, Bibliothèque Nationale du Bénin, 19 p.

[22] Agbodjato, N.A., Noumavo, P.A., Baba-Moussa, F., Salami, H.A., Sina, H., Sezan, A., Bankole, H., Adjanohoun, A. and Baba-Moussa, L. (2015) Characterization of Potential Plant Growth Promoting Rhizobacteria Isolated from Maize (Zea mays L.) in Central and Northern Benin (West Africa). Applied and Environmental Soil Science, 2015, Article ID: 901656.

[23] Guiraud, J. and Galzy, P. (1994) Contrôle Microbiologique dans les Industries Agroalimentaires (2ème eds) Doin.

[24] Wahyudi, A.T., Astuti, R.P., Widyawati, A., Meryandini, A. and Nawangsih, A.A. (2011) Characterization of Bacillus sp. Strains Isolated from Rhizosphere of Soybean Plants for Their Use as Potential Plant Growth for Promoting Rhizobacteria. Journal of Microbiology and Antimicrobials, 3, 34-40.

[25] Aparna, Y. and Sarada, J. (2012) Molecular Characterization and Phylogenetic Analysis of Serratia sp-YAJS An Extracellular Dnase Producer Isolated from Rhizosphere Soil.

[26] Govindappa, M.R.V., Ravishankar, S. and Lokesh (2011) Screening of Pseudomonas Fluorescens Isolates for Biological Control of Macrophomina phaseolina Root-Rot of Safflower. African Journal of Agricultural Research, 6, 6256-6266. https://doi.org/10.5897/AJAR10.1017

[27] Niranjan, R.S., Shetty, N.P. and Shetty, H.S. (2004) Seed Bio-Priming with Pseudomonas Fluorescens Isolates Enhances Growth of Pearl Millet Plants and Induces 
Resistance against Downy Mildew. International Journal of Pest Management, 50, 41-48. https://doi.org/10.1080/09670870310001626365

[28] Yadav, J., Verma, J.P. and Tiwari, K.N. (2010) Effect of Plant Growth Promoting Rhizobacteria on Seed Germination and Plant Growth Chickpea (Cicer arietinum L.) under Vitro Conditions. Biological Forum: An International Journal, 2, 15-18.

[29] Neelesh, K.A., Arvind, K. and Hirdesh, A. (2011) Physiological and Bio-Chemical Changes during Seed Deterioration in Aged Seeds of (Zea mays L.). American Journal of Plant Physiology, 6, 28-35. https://doi.org/10.3923/ajpp.2011.28.35

[30] Khayatnezhad, M. and Gholamin, R. (2011) Effects of Salt Stress Levels on Five Maize (Zea mays L.) Cultivars at Germination Stage. African Journal of Biotechnology, 10, 12909-12915. https://doi.org/10.5897/AJB11.1568

[31] Abdul-Baki, A.A. and Anderson, J.D. (1973) Vigor Determination in Soy Bean Seed by Multiplecriteria. Crop Science, 13, 630-633. https://doi.org/10.2135/cropsci1973.0011183X001300060013x

[32] Ashrafuzzaman, M., Hossen, F.A., Ismail, M.R., Hoque, M.A., Islam, Z.M., Shahidullah, S.M. and Meon, S. (2009) Efficiency of Plant Growth-Promoting Rhizobacteria (PGPR) for the Enhancement of Rice Growth. African Journal of Biotechnology, 8, 1247-1252.

[33] Etèka, A.C. (2005) Comtribution des jachère manioc dans l'amélioration du rendement des cultures et du prélèvement des nutriments: Cas de la succession culturale manioc-maïs au Centre du Bénin. Thèse de DEA, FSA/UAC, Bénin, 107 p.

[34] Kumar, V., Bharti, A., Negi, Y.K., Gusain, O., Pandey, P. and Bisht, G.S. (2012) Screening of Actinomycetes from Earthworm Castings for Their Antimicrobial Activity and Industrial Enzymes. Brazilian Journal of Microbiology, 205-214. https://doi.org/10.1590/S1517-83822012000100022

[35] Olsen, S.R. and Sommers, L.E. (1982) Phosphorus. In: Page, A.L., Ed., Methods of Soil Analysis Part 2 Chemical and Microbiological Properties, American Society of Agronomy, Soil Science Society of America, Madison, 403-430.

[36] Bremner, J.M. (1996) Nitrogen-Total. In: Sparks, D.L., Ed., Methods of Soil Analysis, Part 3, Soil Science Society of America, Madison, 1085-1121.

[37] Knudsen, D., Peterson, G.A. and Pratt, P. (1982) Lithium, Sodium and Potassium. In: Page, A.L., Ed., Methods of Soil Analysis, American Society of Agronomy, Madison, 225-246.

[38] Thomas, G.W. (1982) Exchangeable Cation. In: Page, A.L., Miller, R.H. and Keeney, D.R., Eds., Methods of Soil Analyse, Madison, 154-157.

[39] Ruget, F. and Bonhomme, C.M. (1996) Estimation Simple de la surface foliaire de plantes de maïs en croissance. Agronomie, 16, 553-562. https://doi.org/10.1051/agro:19960903

[40] Nkonge, C. and Balance, G.M. (1982) A Sensitive Colorimetric Procedure for Nitrogen Determination in Micro-Kjeldahl Digests. Journal of Agricultural and Food Chemistry, 30, 416-420. https://doi.org/10.1021/jf00111a002

[41] Ones, J.B.J. and Case, V.W. (1990) Sampling, Handling and Analyzing Plant Tissue Samples. In: Westrman, R.L., Ed., Soil Testing and Plant Analysis, 3rd Edition, SSSA Book Series No. 3, Madison Wisconsin, 389-427.

[42] Murphy, J. and Riley, J.P. (1962) A Modified Single Solution Method for the Determination of Phosphate in Natural Waters. Analytica Chimica Acta, 27, 31-36. https://doi.org/10.1016/S0003-2670(00)88444-5

[43] Igué, M.A., Saïdou, A., Balogoun, I., Ezui, G., Youl, S., Kpagbin, G., Mando, A. and 
Sogbédji, J.M. (2016) Détermination Des Formules D’engrais Minéraux Et Organiques Sur Deux Types De Sols Pour Une Meilleure Productivité De Maïs (Zea mays L.) Dans La Commune De Banikoara (Nord-Est Du Bénin). European Scientific Journal, 12, $16 \mathrm{p}$.

[44] Noumavo, A.P., Kochoni, E., Didagbé, Y.O., Adjanohoun, A., Allagbé, M., Sikirou, R., Gachomo, E.W., Kotchoni, O.S. and Baba-Moussa, L. (2013) Effect of Different Plant Growth Promoting Rhizobacteria on Maize Seed Germination and Seedling Development. American Journal of Plant Sciences, 4, 1013-1021.

https://doi.org/10.4236/ajps.2013.45125

[45] Omar, S.A. (1998) The Role of Rock-Phosphate-Solubilizing Fungi and Vesicular Arbusular-Mycorrhiza (VAM) in Growth of Wheat Plants Fertilized with Rock Phosphate. Word Journal of Microbiology and Biotechnology, 14, 211-2118. https://doi.org/10.1023/A:1008830129262

[46] Cassán, F., Vanderleyden, J. and Spaepen, S. (2014) Physiological and Agro-Nomic Aspects of Phytohormone Production by Model Plant-Growth-Promoting Rhizobacteria (PGPR) Belonging to the Genus Azospirillum. Journal of Plant Growth Regulation, 33, 440-459. https://doi.org/10.1007/s00344-013-9362-4

[47] Koo, S.Y. and Cho, K.S. (2009) Isolation and Characterization of a Plant-Growth Promoting Rhizobacterium, Serratia sp. SY5. Journal of Microbiology and Biotechnology, 19, 1431-1438.

[48] Khalid, A., Arshad, M. and Zahir, Z.A. (2004) Screening Plant Growth Promoting Rhizobacteria for Improving Growth and Yield of Wheat. Journal of Applied Microbiology, 96, 473-480. https://doi.org/10.1046/j.1365-2672.2003.02161.x

[49] Vacheron, J., Desbrosses, G., Bouffaud, M.L., Touraine, B., Moene-Loccoz, Y., Muller, D., Legendre, L., Wisniewski-Dye, F. and Prigent-Combaret, C. (2013) Plant Growth Promoting Rhizobacteria and Root System. Frontiers in Plant Science, 4, 356. https://doi.org/10.3389/fpls.2013.00356

[50] Kifle, M.H. and Laing, M.D. (2016) Effects of Selected Diazotrophs on Maize Growth. Frontiers in Plant Science, 7, 1429. https://doi.org/10.3389/fpls.2016.01429

[51] Chowdhury, A.R. and Sengpta, C. (2016) Isolation and Characterization of Plant Growth Promoting Rhizobacteria (pgpr) from Agricultural Field and Their Potential Role on Germination and Growth of Spinach. IJCAS, 6, 128-131.

[52] Prasad, J.K., Gupta, S.K. and Raghuwanshi, R. (2017) Screening Multifunctional Plant Growth Promoting Rhizobacteria Strains for Enhancing Seed Germination in Wheat (Triticum aestivum L.). International Journal of Agricultural Research, 12, 64-72. https://doi.org/10.3923/ijar.2017.64.72

[53] Babana, A.H., Kassogué, A., Fané, R., Nantoumé, D., Ouattara, D., Maiga, K. and Dao, S. (2018) A Malian Native Plant Growth Promoting Actinomycetes Based Biofertilizer Improves Maize Growth and Yield. Symbiosis, 75, 267-275.

https://doi.org/10.1007/s13199-018-0555-2

[54] Viruel, E., Erazzú, L.E., Calsina, L.M., Ferrero, M.A., Lucca, M.E. and Siñeriz, F. (2014) Inoculation of Maize with Phosphate Solubilizing Bacteria: Effect on Plant Growth and Yield. Journal of Soil Science and Plant Nutrition, 14, 819-831. https://doi.org/10.4067/S0718-95162014005000065

[55] Chakraborty, U.B.N., Chakraborty, A.P. and Chakraborty (2010) Influence of Serratia marcescens TRS-1 on Growth Promotion and Induction of Resistance in Camellia sinensis against Fomes lamaoensis. Journal of Plant Interactions, 4, 261-271. https://doi.org/10.1080/17429140903551738

[56] Devi, K.A., Pandey, P. and Sharma, G.D. (2016) Plant Growth-Promoting Endo- 
phyte Serratia marcescens AL2-16. Enhances the Growth of Achyranthes aspera L., a Medicinal Plant. Hayati Journal of Biosciences, 23, 173-180.

https://doi.org/10.1016/j.hjb.2016.12.006

[57] Matteoli, F.P., Passarelli-Araujoa, H., Reisb, R.J.A., Rochab, O.L, Souzac, M.E, Aravindd, L., Olivaresb, L.F. and Venancio, M.T. (2018) Genome Sequencing and Assessment of Plant Growth-Promoting Properties of a Serratia marcescens Strain Isolated from Vermicompost. CC-BY-NC-ND 4.0 International License.

https://doi.org/10.1101/288084

[58] Riefler, M., Ondrej, N., Miroslav, S. and Thomas, S. (2006) Arabidopsis Cytokinin Receptor Mutants Reveal Functions in Shoot Growth, Leaf Senescence, Seed Size, Germination, Root Development, and Cytokinin Metabolism. The Plant Cell, 18, 40-54. https://doi.org/10.1105/tpc.105.037796

[59] Hameeda, B., Harini, G., Rupela, O.P., Wani, S.P. and Reddy, G. (2006a) Growth Promotion of Maize by Phosphate Solubilizing Bacteria Isolated from Composts and Macrofauna. Microbiological Research, 163, 234-242.

https://doi.org/10.1016/j.micres.2006.05.009

[60] Agbodjato, N.A., Amogou, O., Noumavo, P.A, Dagbenonbakin, G., Hafiz, A.S., Kamirou, R., Alladé, A.M., Adebayo, O., Baba-Moussa, F., Adjanohoun, A. and Ba-ba-Moussa, L. (2018) Biofertilising, Plant-Stimulating and Biocontrol Potentials of Isolated PGPR Rhizobacteria in Central and Northern Benin. African Journal of Microbiology Research, 12, 664-672.

[61] Mezaache, S. (2012) Localisation des déterminants de la suppression de quelques souches de Pseudomonas isolées de la rhizosphère de la pomme de terre. thèse de doctorat, Université Ferhat ABBAS, Sétif, Algérie, 221.

[62] Selvakumar, G., Mohan, M., Kundu, S., Gupta, A.D., Joshi, P., Nazim, S. and Gupta, H.S. (2008) Cold Tolerance and Plant Growth Promotion Potential of Serratia marcescens Strain SRM (MTCC 8708) Isoled from Frowers of Summer Squash (Curcubita pepo). Letters in Applied Microbiology, 46, 171-175. https://doi.org/10.1111/j.1472-765X.2007.02282.x

[63] Arruda, L.A., Beneduzi, A., Martins, B., Lisboa, C., Lopes, F., Bertolo, L., Maria, P., Passaglia, L. and Vargas, K. (2013) Screening of Rhizobacteria Isolated from Maize (Zea mays L.) in Rio Grande do Sul State (South Brazil) and Analysis of Their Potential to Improve Plant Growth. Applied Soil Ecology, 63, 15-22. https://doi.org/10.1016/j.apsoil.2012.09.001

[64] Namlı, A., Mahmood, A., Sevilir, B. and Özkır, E. (2017) Effect of Phosphorus Solubilizing Bacteria on Some Soil Properties, Wheat Yield and Nutrient Contents. $E u$ rasian Journal of Soil Science, 6, 249-258. https://doi.org/10.18393/ejss.293157

[65] Tarafdar, J.C. and Claassen, N. (1988) Organic Phosphorus Compounds as a Phosphorus Source for Higher Plants through the Activity of Phosphates Produced by Plant Roots and Microorganisms. Biology and Fertility of Soils, 5, 308-312. https://doi.org/10.1007/BF00262137

[66] Marschner, H. (1995) Mineral Nutrition of Higher Plants. 2nd Edition, Academic Press, London, 889 p.

[67] Adjanohoun, A., Noumavo, P.A., Sikirou, R., Allagbé, M., Gotoe-chan-Hodonou, H., Dossa, K.K., Yèhouénou, B., Glèlè Kakaï, R. and Baba-Moussa, L. (2012) Effets des rhizobactéries PGPR sur le rendement et les teneurs en ma-croéléments du maïs sur sol ferralitique non dégradé au Sud-Bénin. International Journal of Biological and Chemical Sciences, 6, 279-288. 